Original Research Paper

\title{
Effects of Converting Tropical Peat Swamp Forest into Oil Palm Plantation on Water Quality
}

\author{
${ }^{1}$ Seca Gandaseca, ${ }^{2}$ Noraini Rosli, ${ }^{2}$ Mohd Hanafi Idris, \\ ${ }^{2}$ Osumanu Haruna Ahmed and ${ }^{1}$ Ahmad Mustapha Mohamad Pazi \\ ${ }^{I}$ Department of Forest Production, Faculty of Forestry, \\ University Putra Malaysia, UPM Serdang 43400, Selangor Darul Ehsan Malaysia \\ ${ }^{2}$ Faculty of Agriculture and Food Sciences, Universiti Putra Malaysia, Bintulu Sarawak Campus, \\ Nyabau Road, Post Box No. 396, 97008 Bintulu, Sarawak, Malaysia
}

Article history

Received: 01-04-2015

Revised: 07-05-2015

Accepted: 01-08-2015

Corresponding Author:

Seca Gandaseca

Department of Forest

Production, Faculty of Forestry,

University Putra Malaysia,

UPM Serdang 43400, Selangor

Darul Ehsan Malaysia

Email: seca@upm.edu.my, secags@yahoo.com

\begin{abstract}
Peat swamp forest is a unique forest and wetlands ecosystem that recognized as one of the most important reservoir of biodiversity and water resources protection. Rapid development particularly for development, agriculture and plantation in peat swamp forest (PSF) area had given negative impacts to its ecosystem included degradation of its water quality. This study was conducted to determine water quality condition at undisturbed (natural peat swamp forest) and disturbed (converted peat swamp forest) and to determine its effects of forest conversion on water quality. A total of 324 water samples were collected at Sibu, Tatau, Pandan and Sepadok within two years sampling. Based on Water Quality Index (WQI) by Department of Environment Malaysia; river water at PSF of Sibu and Tatau were found categorized under Class IV (slightly polluted) while river water at Pandan and Sepadok categorized under Class III (moderate) water quality status. The most influence parameter that causes the deteriorating of water quality at Sibu and Tatau is low dissolved oxygen (DO), high concentration of ammonia nitrogen $\left(\mathrm{NH}_{3}-\mathrm{N}\right)$ and chemical oxygen demand (COD) and acidic water $\mathrm{pH}$. Based on this study; river water at PSF of Sibu and Tatau (converted peat swamp forest) could affected and polluted due to agricultural and oil palm plantation activities that took place at the area while compared to river water at PSF of Pandan and Sepadok (natural peat swamp forest) that found categorized under Class III (moderate) water quality status. If proper alternative procedures such as sustainable management of water resources, protection of logging and awareness education of local folk are not undertaken, it could lead to the deterioration of the PSF ecosystem. Strategic management practices and applications of technologies to minimize the impacts to PSF should be done on the surrounding environment in order to preserve this natural heritage and for the sustainable management of the ecosystem and conservation of the PSF and its water resources.
\end{abstract}

Keywords: Water Quality Index, Water Quality Parameters, Natural Peat Swamp Forest, Converted Peat Swamp Forest, Oil Palm Plantation

\section{Introduction}

Tropical peat swamp forests are unique forest and complex ecosystem, rich in biodiversity and comprise variety of flora and fauna. Peat swamp forests (PSF) play a major role in protecting and conserving the quality of environment such as maintaining the carbon balance, biodiversity conservation, stabilizing the ecosystem, microclimate, soil and water resources protection and regulation (Danida, 2006; UNDP, 2006; Yule, 2010; Posa et al., 2011). PSF play a major role in supplying water and act as an important reservoir of water (Shakeran and Tsu, 2001; Yule, 2010) and provide freshwater habitat for aquatic organism.

The center of tropical PSF distribution is located within Malaysia, Indonesia, Vietnam, Thailand and Philippines. 
About 2.5 million of peat swamp forest is still remaining in Malaysia and estimated about 1.6 million peat remains at East of Malaysia, Sarawak. The tropical peat swamps forests have been facing tremendous challenges in the face of development and exploitation lately. Deforestation of Sarawak peat land is accelerate fasters compared to deforestation of all forest where estimate about $8 \%$ of the PSF area has been cleared annually, compared to $2 \%$ on average for all forest in Sarawak (Parish, 2002; Ywih et al., 2009; Teoh, 2011; EPA, 2012). Majority of the forest in Malaysia particularly in Sarawak state which being extensively cleared for agriculture, plantation and development purpose resulting in reduced of biodiversity and cause destruction to PSF.

The increasing rate due to the exploitation of forest areas by various of human activities through deforestation, logging, increasing population pressure, construction, mining, agricultural and plantation activity cause the destruction to PSF ecosystem and generate various problems such as peat degradation, soil loss and serious threat to the water resources in the PSF area (Phillips, 1998; Suwido, 2005; Penguang and Gabriel, 2006; Haraguchi, 2007; Yule, 2010; Hansen et al., 2009; Gray, 2014; Gillies, 2014; Carlson et al., 2014).

Deforestation is also well-known cause fresh water degradation (Carlson et al., 2014). The lack of sustainable management of land development harms the environment, ground water sources, increasing soil salinity and thereby destroying its quality (Clay, 2004). The assessments of environmental effects in urban and rural areas cause by several of human activities through several of land development purposes became very essential for conservation and preservation of its ecosystem and the water resources. If land use on intact PSF continues without control at this rate, all undisturbed and pristine PSF will be destroyed. Source of water supply as provider of freshwater for coastal mangrove forests has been reduced or even eliminated if not manage properly.
Without proper planning, the continuous exploitation, conversion and development of PSF area will cause long-term negative impacts to the environment include degradation of its water resources.

Therefore, this study is conducted to determine water quality of this river and also focuses on investigating different between water quality condition in disturbed (converted) and undisturbed (natural) PSF to achieve sustainable development and better understanding for good management of the effective water resources preservation and conservation.

\section{Materials and Methods}

\section{Description of Study Site}

This study was carried out during dry and wet seasons in the peat swamp forest areas. There are four locations selected at river of Sibu, Tatau, Sepadok and Pandan (Fig. 1). PSF of Sibu and Tatau was a new cultivated oil palm plantation area (disturbed peat swamp forest) which facing land development, deforestation and conversion of forested areas to non-forest land for use particularly for agricultural and oil palm plantation while Pandan and Sepadok are located at primary forest and natural area where there were no villages, settlements, agricultural or plantation activity took place at or near the area (undisturbed peat swamp forest).

\section{Sampling Design}

Water samples collected from four stations from each river located at all study area within two years sampling. Water samples were collected about $10 \mathrm{~cm}$ below water. A total of six replicates of water samples were taken at each station of the river at all study area. The HDPE bottles $(500 \mathrm{~mL})$ and BOD bottles $(300 \mathrm{~mL})$ use to kept water samples and kept in ice with further analyses at laboratory.

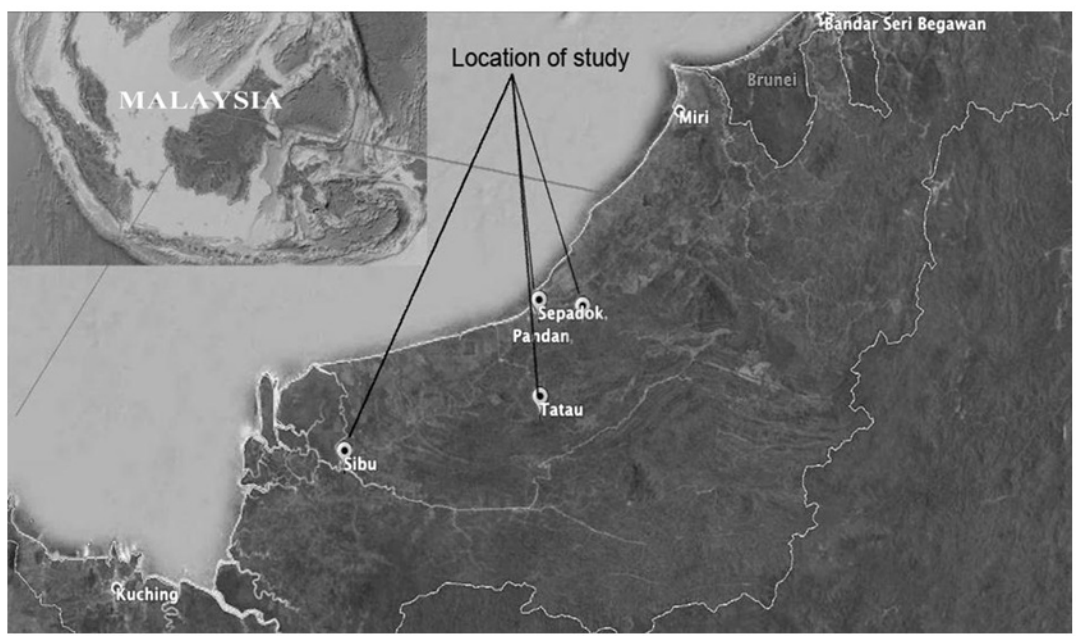

Fig. 1. Location of study area 


\section{Water Quality Measurement}

The data collected for water quality measurement include water temperature (Water Temp), $\mathrm{pH}$, dissolved oxygen (DO), electrical conductivity (EC), salinity (SAL) and turbidity (Turb) were analyzed in field using Hydrolab (Model DS5X) and Water Quality Meter (Model WQC-24). Meanwhile, ammonia nitrogen $\left(\mathrm{NH}_{3}-\right.$ $\mathrm{N})$, biochemical oxygen demand (BOD), chemical oxygen demand (COD), total suspended solids (TSS) and total dissolved solids (TDS) (lab analysis) was analyzed in laboratory. Lab analysis was conducted immediately as the samples were transferred into laboratory to ensure the accuracy of the results. Standard Methods for the Examination of Water and Wastewater by APHA used for measurement of all water quality variables; APHA 5210$\mathrm{B}$ to measure dissolved oxygen, APHA 5220-B to measure COD concentration, APHA 2540-D to measure the total suspended solids (TSS) level, APHA 4500- $\mathrm{NH}_{3}-$ $\mathrm{BC}$ to measure the ammonia nitrogen concentration $\left(\mathrm{NH}_{3}-\right.$ $\mathrm{N})$, APHA 2540-C gives the method for measuring total dissolved solids (TDS) dried at $180^{\circ} \mathrm{C}$. Standard Methods APHA was internationally accepted procedures for measurement of water quality (APHA, 2005). All analyses were tested in six replications. Unit all parameters tested were in milligram/litre $(\mathrm{mg} / \mathrm{L})$, except for $\mathrm{pH}$, electrical conductivity $(\mu \mathrm{S} / \mathrm{cm})$, turbidity (NTU), salinity $\left(\mu \mathrm{Scm}^{1}\right)$ and water temperature $\left({ }^{\circ} \mathrm{C}\right)$.

\section{Data Analysis}

The results of samples taken at all station of the rivers are compared with Water Quality Index (WQI) and National Water Quality Standards (NWQS) Malaysia to classify the status of the river water. WQI widely used in water quality analysis and evaluation. WQI calculated by entered the six important water quality variables mean values including $\mathrm{BOD}, \mathrm{COD}$, DO, $\mathrm{pH}, \mathrm{NH}_{3}-\mathrm{N}$ and TSS into a WQI formula to classify the status of the river water using the following formula: $\mathrm{WQI}=[0.22 \mathrm{X}$ SIDO $]+[0.19 \mathrm{X}$ SIBOD $]+[0.16 \mathrm{X}$ SICOD $]+[0.15 X$ SIAN $]+[0.16 \mathrm{X} \mathrm{SISS}]+[0.12 \mathrm{X}$ $\mathrm{SIpH}$. Degree of river classifications that has been developed by DOE Malaysia is; Very Clean (>92.7) (Class I), Clean (76.5-92.7) (Class II), Moderate (51.976.5) (Class III), Slightly Polluted (31.0-51.9) (Class IV) and Severely Polluted $(<31.0)$ (Class V).

\section{Results}

The results of the water quality analysis are presented in Table 1. The water temperature recorded between studies was relatively high at all study area especially at river water of Sibu and Tatau. The value of river water $\mathrm{pH}$ in this study was found below 5 which at all study area. Dissolved oxygen (DO) showed volume of oxygen available in water. A very low DO found at river water at PSF of Sibu and Tatau, while higher DO level are found at Pandan and Sepadok. Ammonia nitrogen $\left(\mathrm{NH}_{3}-\mathrm{N}\right)$ indicates the pollution from excessive usage of $\mathrm{NH}_{3}-\mathrm{N}$. The major sources of $\mathrm{NH}_{3}-\mathrm{N}$ are usage of fertilizer in agricultural activity. High concentration of $\mathrm{NH}_{3}-\mathrm{N}$ indicated that the river water at the area was polluted by excessive usage of $\mathrm{NH}_{3}-\mathrm{N}$ are from the agricultural, cultivation and oil palm plantation activities that took place at the area. High concentration of $\mathrm{NH}_{3}-\mathrm{N}$ found at Sibu and Tatau where $\mathrm{NH}_{3}-\mathrm{N}$ level at both of the area was found high.

Although all water samples collected recorded high value of $\mathrm{NH}_{3}-\mathrm{N}$ concentrations, however they were below the maximum permissible limit set by World Health Association. The high level of biochemical oxygen demand (BOD) found at Sibu and Tatau. BOD level at Pandan and Sepadok are still in good condition compared to river water of Sibu and Tatau. The chemical oxygen demand (COD) concentration found high at Sibu and Tatau while the value found low at all site of river water at PSF of Pandan and Sepadok. All rivers at all study area have low level of total suspended solids (TSS) that is less than $30 \mathrm{mg} / \mathrm{L}$. The TDS values found in this study are still under permissible limit NWQS Malaysia and World Health Organization. The turbidity level in this study was low and found less than 10 NTU at all study area. On view of electrical conductivity (EC) by compared to the sampling area, the value was not significantly difference.

Water quality sub index (SIDO, SIBOD, SICOD, SIAN, SISS, SIpH) results at all study area and their class of water quality shown in Table 2. River water at PSF Sibu and Tatau was found categorized under Class IV (slightly polluted) while river water at Pandan and Sepadok categorized under Class III (moderate).

Table 1. Mean and standard deviation of each parameter of water quality at all study area

\begin{tabular}{|c|c|c|c|c|}
\hline Parameters/Sampling area & Sibu & Tatau & Pandan & Sepadok \\
\hline Water temperature $\left({ }^{\circ} \mathrm{C}\right)$ & $30.31+0.07$ & $29.4+0.24$ & $28.18+0.01$ & $28+0.40$ \\
\hline $\mathrm{pH}$ & $3.66+0.16$ & $3.9+0.60$ & $4.67+0.06$ & $4.48+0.01$ \\
\hline $\mathrm{DO}(\mathrm{mg} / \mathrm{L})$ & $3.37+0.07$ & $3.86+0.10$ & $4.98+0.14$ & $5.02+0.09$ \\
\hline $\mathrm{BOD}(\mathrm{mg} / \mathrm{L})$ & $3.6+0.08$ & $3.55+0.08$ & $1.78+0.03$ & $2.35+0.09$ \\
\hline $\mathrm{COD}(\mathrm{mg} / \mathrm{L})$ & $38+0.38$ & $39+0.80$ & $16.66+0.90$ & $8.91+0.03$ \\
\hline $\mathrm{EC}\left(\mu \mathrm{Scm}^{1}\right)$ & $80.73+0.01$ & $69.67+0.30$ & $65.25+0.02$ & $58.19+0.11$ \\
\hline TDS (mg/L) & $41+0.87$ & $37+0.32$ & $23+0.12$ & $19+0.09$ \\
\hline TSS (mg/L) & $25+1.71$ & $27.7+1.05$ & $18.05+0.64$ & $10.15+0.91$ \\
\hline Turbidity (NTU) & $6.15+0.01$ & $5.2+0.09$ & $4+0.05$ & $3.8+0.02$ \\
\hline $\mathrm{NH}_{3}-\mathrm{N}(\mathrm{mg} / \mathrm{L})$ & $0.41+0.01$ & $0.38+0.13$ & $0.16+0.13$ & $0.10+0.05$ \\
\hline Salinity $(\%)$ & $0.45+0.04$ & $0.34+0.01$ & $0.05+0.02$ & $0.03+0.01$ \\
\hline
\end{tabular}


Table 2. Water quality sub index parameters results at all study area and their class and water quality status

\begin{tabular}{lllll}
\hline Locations sub index & Sibu & Tatau & Pandan & Sepadok \\
\hline SIDO & 0 & 0 & 0 & 0 \\
SIBOD & 85 & 85 & 93 & 90 \\
SICOD & 55 & 54 & 77 & 87 \\
SIAN & 66 & 68 & 84 & 90 \\
SISS & 84 & 82 & 87 & 92 \\
SIpH & 21 & 26 & 46 & 41 \\
WQI & 51 & 51 & 62 & 64 \\
\hline Class & IV & IV & III & III \\
Water Quality Status & Slightly Polluted & Slightyly Polluted & Moderate & Moderate \\
\hline
\end{tabular}

*SIDO: Sub Index dissolved oxygen, SIBOD: Sub Index biochemical oxygen demand, SICOD: Sub Index chemical oxygen demand, SIAN: Sub Index ammoniacal nitrogen, SISS: Sub Index total suspended solids, SIpH: Sub Index pH.

\section{Discussion}

Water temperature could be influenced by the lack of canopy cover, its shallowness and stagnant water condition. From observation, no canopy cover found at and near river of Sibu and Tatau because has been cut down and cleared for oil palm plantation cultivation purposes. Carlson et al. (2014) reported, water temperature in streams that draining was nearly $4^{\circ} \mathrm{C}$ warmer than a stream draining in the intact forest. The area of Sebauh and Sepadok surrounding by a lot of small and big trees that serve as canopy cover and this is the reason the water temperature of the area were still low compared to river water at PSF of Sibu and Tatau.

The $\mathrm{pH}$ value is not within the potable limit and the US EPA considers water bodies with $\mathrm{pH}$ less than 5 is acidified and harmful water condition. The area of peat swamp is known with low water $\mathrm{pH}$ values and has extreme acidic environment of its water bodies. These values are considered normal range condition for river water at PSF which is normal characteristics of peat swamp water which is acidic water condition. This is also the reason for consistent results which is low and acidic $\mathrm{pH}$ found at all of study area. Therefore it is important to protect the aquatic ecosystem from both excessive acidic and pollution. Both low and high water $\mathrm{pH}$ will be corrosive and harmful to an aquatic organism.

According to DO result, there is an indication that river water conditions of river water at natural PSF (undisturbed) are still having better DO than river water at plantation (disturbed) area. Amount of oxygen that can be hold by water also depends on water temperature. Colder water condition can hold higher concentration of DO compared to warm water. Low oxygen levels weaken an aquatic life which will lead to illness and disease and cause death to fish and variety of aquatic organism.

Warm water that affect by hot temperature also contribute to low DO level. The main causes of low DO at Sibu and Tatau is because of hot water temperature and the pressure of high organic matter content which causes lack of oxygen in water. From observation, there is a lot of organic matter such as debris, leaves and wood at river water of Sibu and Tatau and its come from shrubs and trees that had been cut down to clear the land for development of oil palm estate. A lot of trees and shrubs cleared from the land in this area and it's was disposed into river and this contributes to the enrichment of an organic matter.

Generally, in natural and normal condition, the PSF is a place of an accumulation of $100 \%$ of pure organic material. This is also the reason for low DO concentration of stream water at Pandan and Sepadok even there is no clearing and land activities took place at the area. However, the value is still better compared to Sibu and Tatau.

The clearing activities cause deteriorating on water quality in PSF. There are several of problem effects by deforestation, clearing the forest and land development such as surface erosion. According to ECD (2000), the clearing activity cause erosion and the sediment that delivered to streams will cause problems on water flow and poor water retention which lead to water deterioration. Moreover, once peat develops hydrophobicity, its water holding capacity could not be restored. Therefore, it is important to maintain hydrological function, not only to regulate water flow but also to maintain underground water pressure in order to prevent salt-water intrusion ( $\mathrm{Ng}$ and Shamsudin, 2001).

The value of DO in water also act as an indicator to know what type of fish and aquatic life will survive and to what extent the aquatic life may live in the water bodies. The DO levels in river water should be high and enough for the normal and healthy life of all species of the aquatic organisms. When the DO is not enough, all these organisms were under pressure or death. In aquatic systems, excessive organic and inorganic input into water bodies may reduce the availability of oxygen. Low concentration or no dissolved oxygen cause low fish productivity and also lead to fish kill.

There are only certain type of an aquatic plant and aquatic fish can capable to survive in acidic water condition. Only few of aquatic plant such as Ipomea aquatica, Cryptocoryne longicauda and Eichhornia crassipers and fish such as Anabas testidineus, 
Helostoma temminckii and Clarias teijsmanni found in the water bodies of PSF specifically in river water of Sibu and Tatau. Both of the river at the area was discharge by the high content of organic matter that causes lack of oxygen in the water making impossible for aquatic life to live and difficult for fish to survive in the water due to the lack of aquatic plants which was their food sources.

While compared to river water at Pandan and Sepadok, there are many aquatic plant overgrown in the river water include Cryptocoryne longicauda, Cryptocoryne yujii, Eichhornia crassipers, Ipomea aquatica and others fish such as Anabas testudineus, Clarias batrachus, Clarias teijsmanni, Helostoma temminkii, Mystus sp, Osphronemus gouramy, Rasbora pauciperforata, Trichogaster trichopterus, Trichogaster pectoralis and many more indicated that DO level is still enough to support aquatic life in the water bodies. The aquatic plants provide aeration to the water through photosynthesis process and this is the reason DO level at both of the area are high compared to river water at Sibu and Tatau. River water of Sibu and Tatau was a stagnant river water condition. The flowing water is high in DO compare to the stagnant water and vice versa. The river water at the study area is under low flow condition and this causing low DO levels in the drainage. Low DO of water was normal conditions which are exhibit typical characteristics of peat swamp water. Similar conditions for DO were reported by Gasim et al. (2007) at river water of PSF of Bebar River, Pahang with DO ranging from $0.54-1.76 \mathrm{mg} \mathrm{L}^{-1}$.

Same result of DO value found at PSF of Loagan Bunut Marudi Sarawak ranging from 0.75-4.33 $\mathrm{mg} \mathrm{L}^{-1}$ record by Lau Seng et al. (2005) and DO at PSF of Beriah Swamp Perak which found ranging from 1.21$2.14 \mathrm{mg} \mathrm{L}^{-1}$ found by Mashhor et al. (2004). Warm and high temperature at all study area specifically river water at Sibu and Tatau also make the DO level become low because only little amount of DO it's able to hold.

The high concentration of $\mathrm{NH}_{3}-\mathrm{N}$ at river water at PSF of Sibu and Tatau was cause by the usage of agrochemicals such as fertilizer. When fertilizer applied for crop production on peat soil which is normally having high porosity; it will cause fast leaching of nutrients into water bodies and seriously affects the freshwater and the aquatic life. Irrigation and draining activity at the area also affects the water resources by transporting the pesticides, chemical, nutrients, sediment, pathogen, heavy metals and salts.

Since this plantation was located near the river, there might be possibilities that surface runoff occur due to the rain fall and then washes the pollutant into water bodies. The applications of fertilizers and runoff of nutrients give negative impacts on water quality which cause excessive algal growth and prevent sunlight from reaching aquatic life in deeper water and also leading to deoxygenating of water. The input of sediment into rivers leads to damage to fish populations and also cause death to fish and aquatic organism.

Improper management of agriculture waste especially from oil palm plantation contributes to increase the $\mathrm{NH}_{3}$ $\mathrm{N}$ level in water at the area. Organic materials also contribute to produce $\mathrm{NH}_{3}-\mathrm{N}$ in water. In addition, other source of $\mathrm{NH}_{3}-\mathrm{N}$ is causing by the anaerobic decomposition of organic matter mainly from leaf, branch and debris from plant and tree that have been cut down at the area. Increasing number of $\mathrm{NH}_{3}-\mathrm{N}$ level in water is very toxic and harmful the aquatic life in water bodies.

From the observation of river water at Sibu and Tatau, there are just very little of aquatic plant and aquatic life found at river of the area. This is because of high concentration of $\mathrm{NH}_{3}-\mathrm{N}$ that have pollutes the river at the area make it difficult for aquatic life to survive. River water at natural PSF of Pandan and Sepadok was growing with variety of aquatic plant because it is an undisturbed PSF where there were no villages, settlements, agricultural or plantation activity took place at and near the area. This showed that the river at the area did not polluted by excessive usage of $\mathrm{NH}_{3}-\mathrm{N}$ where $\mathrm{NH}_{3}-\mathrm{N}$ concentration at both of river water found in low concentration.

BOD is one of essential variable in order to measure an organic pollutant level cause by domestic wastes or agricultural waste. Usage of fertilizer and pesticides application at oil palm plantation of Sibu and Tatau has polluted the river water at both of the area which increases its BOD level. Pollutants such as construction effluent, fertilizer, agricultural waste and organic matter discharged from estate development into PSF affect the forest's water quality at the area. Acidification of water bodies also increased the BOD level. The value of BOD continuously rise when there is more organic matter such as leaves, wood and debris in the river water. Organic matters in the form of shrubs and trees that had been cut down to clear the site near and at river water of Sibu and Tatau increase the BOD level at both of the area. It was similar to the finding of Francis et al. (2006) which state that microbial decomposition of wastes and plant materials exerts high BOD and creates anaerobic conditions.

The deteriorating of water quality can be measured with high value of COD and vice versa. The high concentration of COD in the surface water also indicated that the solid waste is highly polluted with organic and inorganic pollutants. The COD concentration in unpolluted surface waters is less than $25 \mathrm{mg} \mathrm{L}^{-1}$ as found at both of river water at PSF of Pandan and Sepadok. The moderately high level of COD value at river water at PSF of Sibu and Tatau indicated that the river water in the area was polluted with organic and inorganic pollutants while low 
concentration of COD at river water at Pandan Sebauh and Sepadok indicated that the water of the area was not having heavy organic and inorganic pollutants.

The source of these sediments origin naturally or cause by human activities in the watershed such as excessive soil erosion from agricultural, construction or land development. Low level of TSS at all study area suggests that there was no heavy erosion taken place along the study area. The mean value of the TSS is moderately high because of the harvesting activity in the area. Some value probably originated from decomposition of nonpoint sources pollutant in water. Then after some period of time, the suspended solid goes through decomposition processed which increase TSS.

The total dissolved solids (TDS) come from organic sources and other sources such as runoff from urban area and inorganic materials such as rocks. The water in this study area has low pollution level due to the TDS values still under permissible limit NWQS Malaysia and World Health Organization.

According to International Standards and Department of Environment Malaysia, the acceptability of water for domestic use ranges from 5-25 NTU. Low level of turbidity in the study area suggests that there was no heavy erosion taken place at and near river water at all study area.

According to Carol (1993), the natural concentration of salts in waterway is largely influenced by geology of the area though which the water flows. Streams that run through areas with clay soils tend to have higher EC because of presence of materials that ionize when washed into water. Usually, high EC values indicate the presence of high content of dissolved salts in the river water and the EC values are a good measure of the relative difference in water quality between different aquifers. EC can also affected by temperature where the warmer the water, the higher value of EC. The river water at PSF generally has low EC because discharges by high amount of organic matter which include dissolved and suspended material. Low level of EC at all study area was natural condition for peat swamp water. Furthermore, the river water especially at Sibu and Tatau discharges by high amount of organic matter and this is the reason for the low of its EC value.

Physically, both of river water at PSF of Sibu and Tatau has shallow water compared to river water at PSF of Pandan and Sepadok. This is because the PSF cover has been removed and the peat lands of the area have been drain for construction and modification for agricultural and oil palm plantation purposes. As an example, peat lands of Florida's Everglades which are shrinking at rate of $2.5 \mathrm{~cm}$ per year due to extensive drainage for agriculture and histosols of the SacramentoSan Joaquin delta in California settled at a rate of up to 8 $\mathrm{cm} /$ year between 1922 and 1950 (Rojstaczer and Deverel, 1995). Same situation reported by Wöstena et al. (1997) at PSF of Malaysia where average subsidence rate for the study area was found to be $2 \mathrm{~cm}$ per year. Moreover, research by Deltares (Hooijer et al., 2010; 2012) also has shown many of PSF of Malaysia has been drained for oil palm and other plantation causing peat land subsidence typically 1 to 2 meters in just one year after drained. Sawal (2003) reported; any change of water table and other modification in the PSF area resulting in changes of the peat ecosystem and also causing ecological imbalance and drying of the forest substrate therefore reducing its function and capacity to act as a reservoir during dry seasons such as store water. Moreover, some cases of water shortage also occur at several districts in Sarawak; include both disturbed forest as found in this present study area.

\section{Conclusion}

This study revealed that due to conversion of PSF into palm oil plantation on water quality had deteriorated significantly as was evident from spatial variation of water quality variables found in this study. Poor water quality can be the result of natural processes of river water at PSF (low dissolved oxygen and acidic $\mathrm{pH}$ ) but is more often associated with human activities and is closely linked to the agricultural and plantation development activities. Human activities and pollutants discharged particularly waste from agriculture and plantation activities into PSF severely affects the PSF water quality such as acidification of water, increasing level of BOD and COD and contribute to high concentration of $\mathrm{NH}^{3}-\mathrm{N}$ as found at both of study area of Sibu and Tatau (disturbed peat swamp forest) compared to river water of Pandan and Sepadok (undisturbed peat swamp forest) that still having a good water quality status. This study suggested that PSF of Sibu and Tatau and the surrounding area should be preserve to maintain its water quality and aquatic life. Agencies involved in this situation should be more effective in preserving this forest. The need to conserve and restore the pristine PSF in the Sarawak Malaysia is clearly urgent. PSF should be managing properly and greater efforts must be given to prevent the destruction to the PSF ecosystem and for conservation of its water resources.

\section{Acknowledgment}

Thanks to Ministry of Higher Education Malaysia and Universiti Putra Malaysia for funding this research. Sincerely thanks to staff of Universiti Putra Malaysia Bintulu Sarawak Campus for their help during fieldwork and laboratory experiment. Special thanks to Forest Department of Sarawak and Sarawak Forestry Corporation for their help and cooperation. 


\section{Funding Information}

This work was supported and funded by the Ministry of Higher Education Malaysia and Universiti Putra Malaysia.

\section{Author's Contributions}

This study is the result of the full and equal collaboration of all the authors.

\section{Ethics}

This article is original and contains unpublished material. The corresponding author confirms that all of the other authors have read and approved the manuscript and no ethical issues involved.

\section{References}

APHA, 2005. Standard Methods for Examination of Water and Wastewater. 21st Edn., APHA, Washington, pp: 158.

Haraguchi, A., 2007. Effect of sulfuric acid discharge on river water chemistry in peat swamp forests in central Kalimantan, Indonesia. Limnology, 8: 175-182. DOI: $10.1007 /$ s 10201-007-0206-4

Carlson, K.M., L.M. Curran, A.G. Ponette-González, D. Ratnasari and Ruspita et al., 2014. Influence of watershed-climate interactions on stream temperature, sediment yield and metabolism along a land use intensity gradient in Indonesian Borneo. J. Geophys. Res. Biogeosci.

DOI: $10.1002 / 2013$ JG002516

Carol, 1993. Quality assurance and quality control plan with water quality monitoring plan for the dillenbaugh creek model watershed project. Lewis Conservation District.

Clay, J., 2004. World Agriculture and the Environment: A Commodity-By-Commodity Guide to Impacts and Practices. 1st Edn., Island Press, ISBN-10: 1559633700, pp: 570.

Danida, 2006. Malaysia's peat swamp forests conservation and sustainable use. United Nations Development Programme.

EPA, 2012. Joint Science and environmental stakeholder comments on: Docket No. EPA-HQ-OAR-20110542: EPA's analyses of palm oil used as a feedstock under the Renewable Fuel Standard (RFS) program. Environmental Protection Agency.

ECD, 2000. Environmental Impact Assessment (EIA) Guidelines for oil palm plantation development. Third Draft. State Environmental Conservation Department, Sabah Malaysia.

Francis, O.A., B.I. Robert and C.O. Efe, 2006. The impact of sawmill wood wastes on the water quality and fish communities of Benin River, Niger Delta Area, Nigeria. World J. Zool., 1: 94-102.
Gasim, M.B., B.S. Ismail, M.E. Toriman, S.I. Mir and C.C. Tan, 2007. A physico-chemical assessment of the Bebar River, Pahang, Malaysia. Global J. Environ. Res., 1: 7-11.

Hansen, M.C., S.V. Stehman, P.V. Potapov, B. Arunarwati and F. Stolle et al., 2009. Quantifying changes in the rates of forest clearing in Indonesia from 1990 to 2005 using remotely sensed data sets. Environ. Res. Lett. DOI: $10.1088 / 1748-9326 / 4 / 3 / 034001$

Hooijer, A., S. Page, J.G. Canadell, M. Silvius and J. Kwadijk et al., 2010. Current and future $\mathrm{CO}_{2}$ emissions from drained peatlands in Southeast Asia. Biogeosciences, 7: 1505-1514. DOI: $10.5194 /$ bg-7-1505-2010

Hooijer, A., S. Page, J. Jauhiainen, W.A. Lee and X.X. Lu et al., 2012. Subsidence and carbon loss in drained tropical peatlands. Biogeosciences, 9: 1053-1071. DOI: $10.5194 /$ bg-9-1053-2012

Gillies, J., 2014. Rapid growth of oil palm plantations threatens stream water quality. Environmental monitor. Application and technology news for environmental professionals.

Wöstena, J.H.M., A.B. Ismailb and A.L.M. van Wijka, 1997. Peat subsidence and its practical implications: A case study in Malaysia. Geoderma, 78: 25-36. DOI: 10.1016/S0016-7061(97)00013-X

Posa, M.R.C., L.S. Wijedasa and R.T. Corlet, 2011. Biodiversity and conservation of tropical peat swamp forests. BioScience, 61: 49-57.

DOI: 10.1525/bio.2011.61.1.10

Lau Seng, M., Mohamed, K., Apun, A.B.C., Hong, T.M., Guan and A., Sayok, 2005. Water quality of Loagan Bunut, Marudi, Sarawak. Scientific Journey Through Borneo: Loagan Bunut-the Wetland Heritage of Sarawak.

Mashhor, M., A. Ahyaudin, R. Jack, A. Abu Hassan and M. Asyraf, 2004. Tropical Peat Swamps: Safeguarding a Global Natural Resource. 1st Edn., Penerbit Universiti Sains Malaysia, Pulau Pinang, ISBN-10: 9832514584, pp: 356.

Gray, N., 2014. Palm oil plantations threaten water quality, warn researchers. William Reed Business Media.

Ng, T.P and I. Shamsudin, 2001. Common Trees in Peat Swamp Forest of Peninsular Malaysia. 1st Edn., Forest Research Institute Malaysia, Kuala Lumpur, ISBN-10: 9832181070, pp: 97.

Parish, F., 2002. Overview on peat, biodiversity, climate change and fire. Global Environment Centre.

Penguang, M. and T. Gabriel, 2006. Managing the maludam agro-ecosystem Sarawak, Malaysia. Sarawak Forestry Department, Malaysia.

Phillips, V.D., 1998. Peat swamp ecology and sustainable development in Borneo. Biodiversity Conservat., 7: 651-671. DOI: 10.1023/A:1008808519096 
Rojstaczer, S. and S.J. Deverel, 1995. Land subsidence in drained histosols and highly organic mineral soils of California. Soil Sci. Soc. Am. J., 59: 1162-1167. DOI: $10.2136 /$ sssaj 1995.03615995005900040031x

Sawal, P., 2003. Threats to Peat Swamp Forest of Sarawak. 1st Edn., Alterra, Wageningen, pp: 61.

Suwido, H.L., 2005. Restoration and wise use of tropical Peatland: Problems of biodiversity, fire, poverty and water management. Indonesian Journal of University Palangka Raya.

Shakeran, M.S. and C.H. Tsu, 2001. Peat water catchment area, Proceedings of the Workshop on Water Management for Sustainable Agricultural Development of Peatland, Mar. 28-29, Damai, Kuching.
Teoh, S., 2011. Palm oil risks all Sarawak peat forests by 2020. Edge Insider Sdn Bhd.

UNDP, 2006. Malaysia's peat swamp forests conservation and sustainable use. United Nations Development Programme.

Yule, C.M., 2010. Loss of biodiversity and ecosystem functioning in Indo-Malayan peat swamp forests. Biodivers Conserv., 19: 393-409. DOI: $10.1007 / \mathrm{s} 10531-008-9510-5$

Ywih, C.H., O.H. Ahmed, N.M.A. Majid and M.B. Jalloh, 2009. Effects of converting secondary forest on tropical peat soil to oil palm plantation on carbon storage. Am. J. Agri. Bio. Sci., 4: 123-130.

DOI: $10.3844 /$ ajabssp.2009.123.130 